\title{
An Analysis of the Recent Situation and Problems in the Cutting Reporting System
}

\author{
Koji Matsushita*
}

\begin{abstract}
This paper clarifies the current status of the cutting reporting system in Japan. This system was enacted as part of the Forest Law after the Second World War. Initially, a cutting permission system was introduced, and this was later changed to the current cutting reporting system. Recently, the percentage of forest owners filing cutting activities by the cutting reporting system has been low. As a result, several problems have occurred, for example, the forest resource database can not be updated. To determine the reasons why forest owners do not file the cutting reporting form, a questionnaire was conducted in July 1995, and responses were obtained from 666 forest owners and 33 forest advisors. It was found that: (1) The percentages of forest owners and forest advisors who are familiar with the cutting reporting system are $49.1 \%$ and $66.7 \%$, respectively. Over $20 \%$ of both categories are not even aware of the existence of the system. (2) The percentages of forest owners and forest advisors who filed all cutting activities during the past five years were $12.2 \%$ and $5.0 \%$, respectively. There were many forest owners who did not file cutting reports even though they were aware of the system. (3) The reasons why forest owners do not file the report are not only a lack of familiarity with the system and its requirements, but also erroneous or deliberate misinterpretation of the system, i.e., a cutting report is not required if cutting activities are small in size. (4) Of the forest advisors, $45.5 \%$ recognize the necessity of reporting cutting activities for the promotion of the local forestry program. The importance of the cutting reporting system and the possibility of promoting its use are discussed and six policy recommendations are presented. Most notably, increased publicity must be started as soon as possible.
\end{abstract}

Keyword: cutting reporting system, cutting age, forest owner, questionnaire survey, Forest Law

\section{INTRODUCTION}

As cutting activity is the most important forestry practice, governments have made an effort to obtain correct information about such activities. The cutting reporting system requires that forest owners or logging companies who are planning to cut trees in non-national forests to report the cutting plan before proceeding. The system is an important management tool in prefectural governments.

The cutting reporting system is part of the forest planning system in Japan, and is based on the Forest Law. The forest planning system, especially in cases involving

* Faculty of Agriculture, Kyoto University, Kitashirakawa - Oiwake - Cho, Sakyo-ku, Kyoto 606-01 Japan the local planning system, is primarily for managing timber production in Japan. Many non-timber utilities are also considered in the forest planning system, but these are generally added factors. However, non-timber values of forests have become more important and as a result, the role of the cutting reporting system is thought to be changing. In addition, recently different types of cutting activities, other than clear cutting, have become more common, and it is important for the local forest planners to obtain correct information on cutting activities.

In Japan, Gifu prefecture is well known for its forest resources information system which uses various kinds of forestry policy programs, including a cutting reporting form. Using a forest resource database connected to the cutting reporting system, SHIRAISHI (1994) studied the intensity of forestry operations from the perspective of accessibility. IWATA and FuJIWARA (1994) and MATSUSHITA 
et al. (1994) also used the database of Gifu prefecture to analyze cutting activities. In the absence of a database connected to the cutting reporting system, cutting activities must be analyzed by calculations based on the cutting reporting forms at the local prefectural government offices or local forest owners associations. In 1992, MAtsushitA et al. calculated that 3,685 cutting reporting forms were available for analysis.

The most important and well-known problem of the cutting reporting system is that the proportion of people who understand the system is low, so, many forest owners tend not to report their cutting activities to the prefectural government. For example, YAMAUCHI et al. (1994) pointed out that the ratio of cutting volume estimated by cutting reports was $70 \%$ of the cutting volume from clear cutting in Ibigawa Forest Planning Area in Gifu prefecture, the prefecture with the most developed forestry information system in Japan. In cases involving cutting methods other than clear cutting, the percentage must be considerably lower, even in Gifu prefecture. Figures like these are not released to the public by the prefectural governments, but reported cutting activity is estimated to be less than $50 \%$ in most areas. As a result, local governments can not obtain correct information on cutting activities.

This paper investigated the current situation and problems in the cutting reporting system in Japan. It is important to clarify the forest owners' attitudes toward the cutting reporting system if the program is to be reformed in the future. Therefore, a questionnaire on cutting activities and the cutting reporting system was conducted in Hokusatsu Forest Planning Area in Kagoshima prefecture in 1995, and the main findings are presented in this paper. The current role of the cutting reporting system and the policy recommendations for the reform of this program are discussed.

\section{SUMMARY OF THE CUTTING REPORTING SYSTEM IN JAPAN}

The cutting reporting system was established under the Forest Law (enacted in 1951, last revision 1991). According to Article 10, forest owners who are planning to cut trees in non-national forests are required to report their cutting plan to the prefectural governor 30 to 90 days before cutting. The report must include the place, cutting area, cutting method and cutting age of the forest, and other related matters specified by Ministerial ordinance. Article 10 also specifies exceptional cases. Article 207 specifies penal provisions for the cutting report. A fine not exceeding 300,000 yen (approximately US $\$ 3,000$ ) shall be imposed upon a forest owner who cuts trees in nonnational forests without filing a cutting report.

The standard cutting report form shown by SHINRIN
KeIkaku Seido Kenkyukai (1992) includes the following items: cutting place, cutting area, classification of final cutting or thinning, classification of clear cutting or selective cutting, cutting ratio, cutting species, cutting age, period for cutting activities and utilization after cutting (for example, farm). A remarks column is included to note the reforestation method after cutting and restrictions on forestry practice under specific laws and regulations such as national park regulations. In the case of protected forests, a separate application for cutting permission is needed.

The cutting report is useful for forest planning. First, to maintain a correct database on forest resources, accurate data on cutting activities is necessary. If forest owners do not file cutting reports, local governments can not update their forestry databases and, as a result, high-aged forests which have already been cut down will be shown as continuing to grow in the database. Another important role of cutting reporting system is to clarify the trends of cutting activities in real time.

One of the basic ideas of Japanese forestry policy after the Second World War, especially forest resource policy, was to ensure freedom in forestry management. After the war, domestic forest resources could not satisfy the high timber demand of the postwar recovery period. Consequently, a permission system for tree-cutting was introduced in the first Forest Law after the war, in 1951. This system was changed to the cutting reporting system under the revision of the Forest Law in 1962. Since then, the cutting report has become the main source of information about cutting activities for prefectural governments. Another important source of information is the subsidy program. Recently, almost all planting has been done with subsidies from the Forestry Agency of the Japanese Government. To be eligible for the subsidy, forest owners must file a cutting report, which allows local government to update the database on forest resources. However, where forestry practices are not subsidized, it is difficult for local governments to obtain information.

\section{FOREST OWNERS' ATTITUDES TOWARD THE CURRENT SYSTEM}

Summary of survey area and forest owners

The survey was undertaken in the Hokusatsu Forest Planning Area in Kagoshima prefecture, in the southern part of Kyushu. Sendai River is the main river in this forest planning area. The total forest area in Hokusatsu Planning Area is 127,648 ha, $74.3 \%$ of which is privately owned. The main species are Chamaecyparis obtusa (37.1\%), Cryptomeria japonica (20.5\%) and broad-leaved trees $(31.0 \%)$. The total standing volume in 1992 was 
$17,975,000 \mathrm{~m}^{3}$, and the average standing volume per ha was $140.7 \mathrm{~m}^{3}$. The annual cutting volume was between $200,000 \mathrm{~m}^{3}$ and $250,000 \mathrm{~m}^{3}$ between 1989 and 1993. In this forest planning area, there are 17,545 forest owners according to the 1990 Agriculture and Forestry Census, and 11,508 of these owned less than 1ha. There are 6 forestry owners associations in the area. In July 1995, a questionnaire was conducted among the representative forest owners (called Soudai, total number 1,194$)$ listed with these associations and forest advisors (called Shidou rinka, total number 93) in this planning area. Of these, 666 representative forest owners and 33 forest advisors responded, the response rates of $55.8 \%$ and $35.5 \%$, respectively. It is desirable to present a profile of representative forest owners and their forest management practices before moving on to the main task. The following items were clarified by the questionnaire.

The average age of forest owners is 64.4-years-old, and the average age of the forest workers (usually the forest owner and his family, but occasionally including temporary employees) is 62.9-years-old for men and 61.0 -years-old for women. The issues related to an aging society that are common in all Japanese industries are also found in forestry, where there is a high percentage of old people among private forest owners and forestry workers. The main sources of income for forest owners were annuity $(27.5 \%)$, agriculture $(26.4 \%)$ and salary (14.9\%). Only $2.6 \%$ of owners indicated that their most important income source was forestry. The percentage of forest owners who had any income during the past five years from the forestry sector, including minor forest products such as mushrooms, was only $13.9 \%$.

The average forest holding was 4.4 ha. The number of forest owners classified by the size of their holding was as follows: $14.1 \%$ (less than 1 ha) , $64.3 \%$ (1-5 ha), $12.3 \%$ (5-10 ha), $5.4 \%$ (10-20 ha), $3.8 \%$ (larger than 20 ha). This is typical of forest holdings in Japan, where the management area is very small and this small area is divided into several stands. Most forest owners have artificial forests, mainly of Cryptomeria japonica and Chamaecyparis obtusa. For $41.7 \%$ of forest owners, over $80 \%$ of their forest was artificial, and for $60.5 \%$, over $50 \%$ was artificial. A high proportion of forest owners (39.9\%) did not have any artificial forests older than 41 years, the standard rotation age in this forest planning area. Most artificial forests in the area are in the age-class that require tending.

The percentage of forest owners who worked in the forest during the past five years is shown in Table 1 . Overall, $27.1 \%$ of forest owner did not perform any of the work listed in this table. The forest practices commonly done by the owner are thinning of trees less than 35 years old $(62.0 \%)$, pruning $(59.7 \%)$, weeding $(57.8 \%)$ and cleaning-cutting $(56.1 \%)$. The main labor force is the forest owner, his family and forest workers from the forest owners associations. In thinning and final cutting, the role of the forest owners association is important. The survey area had suffered typhoon damage in 1993, and a number of forest owners had been doing salvage work. The rates of activity shown in Table 1 are slightly higher than expected because of the typhoon damage.

Generally, the logs produced by thinning do not always sell. For example, the percentage of forest owners who sold all logs produced by thinning forests less than 35 -years-old was only $14.7 \%$ and $43.9 \%$ of forest owners could not sell any logs produced by thinning. The percentage of forest owners who used even a small portion of

Table 1 Forest practices during the past 5 years

\begin{tabular}{|c|c|c|c|c|c|c|c|c|}
\hline \multirow[t]{2}{*}{ Forest practice } & \multicolumn{2}{|c|}{ Total } & \multicolumn{2}{|c|}{ Family } & \multicolumn{2}{|c|}{ Cooperatives $^{1)}$} & \multicolumn{2}{|c|}{ Other } \\
\hline & Number & Ratio & Number & Ratio & Number & Ratio & Number & Ratio \\
\hline Planting & 105 & 22.4 & 61 & 13.0 & 32 & 6.8 & 12 & 2.6 \\
\hline Weeding & 271 & 57.8 & 149 & 31.8 & 98 & 20.9 & 24 & 5.1 \\
\hline Pruning & 280 & 59.7 & 155 & 33.0 & 98 & 20.9 & 27 & 5.8 \\
\hline Cleaning cutting & 263 & 56.1 & 116 & 24.7 & 124 & 26.4 & 23 & 4.9 \\
\hline Climber cutting & 165 & 35.2 & 78 & 16.6 & 73 & 15.6 & 14 & 3.0 \\
\hline Thinning ( $1-35$ years) & 291 & 62.0 & 117 & 24.9 & 153 & 32.6 & 21 & 4.5 \\
\hline Thinning (over 36 years) & 78 & 16.6 & 24 & 5.1 & 45 & 9.6 & 9 & 1.9 \\
\hline Clear cutting (artificial forest) & 92 & 19.6 & 9 & 1.9 & 76 & 16.2 & 7 & 1.5 \\
\hline Clear cutting (natural forest) & 39 & 8.3 & 6 & 1.3 & 27 & 5.8 & 6 & 1.3 \\
\hline Natural forest improvement & 22 & 4.7 & 7 & 1.5 & 9 & 1.9 & 6 & 1.3 \\
\hline Multi-storied forest & 5 & 1.1 & 3 & 0.6 & 0 & 0.0 & 2 & 0.4 \\
\hline Forest road construction & 15 & 3.2 & 2 & 0.4 & 10 & 2.1 & 3 & 0.6 \\
\hline Spur road construction & 33 & 7.0 & 6 & 1.3 & 21 & 4.5 & 6 & 1.3 \\
\hline Other & 9 & 1.9 & 1 & 0.2 & 7 & 1.5 & 1 & 0.2 \\
\hline
\end{tabular}

Note: 1) Forest owners associations. 
thinning for domestic consumption was $37.1 \%$. It is worth noting that thinning does not always produce income in Japan.

Recognition of the cutting reporting system

Several questions related to the cutting reporting system were prepared for the forest owners' questionnaire. The forest owners surveyed were divided into 2 groups, namely, representative forest owners of local forest owners associations and forest advisors in the survey area. The advisory system is managed by the prefectural government, and the main objective of the system is to support the forest owners by providing local forestry extension services. In this analysis, representative forest owners are called Group A and forest advisors are called Group B.

The awareness among forest owners of the cutting reporting system is shown in Table 2 . The percentage of the forest owners who were not aware of the existence of the system was $25.2 \%$ in Group A and $21.2 \%$ in Group B. The cutting reporting system is a basic and important policy program for forest resource management and is specified in the Forest Law, a basic law on forest resources and forestry. Nevertheless, one-fourth of forest owners and over one-fifth of forest advisors, do not even know of the existence of the system. Extensive publicizing of the cut- ting reporting system is strongly recommended in the light of this finding. The percentage of forest owners who indicated awareness of the system was $49.1 \%$ in Group A and $66.7 \%$ in Group B. It is not clear what percentage of forest owner know the actual contents of the cutting reporting system, for example, the exceptional rule, as there were no questions in the questionnaire to check whether forest owners knew the details of the system. It should be required that forest advisors in the prefectural government understand the contents of the system.

The current percentage of owners who file cutting reports is summarized in Table 3. In Group A, 55.9\% of forest owners answered that they have not cut at all during the past five years. When compared to the forestry activity rates shown in Table 1 , it seems that the forest owners who did not answer must have cut trees during the past five years, so a second ratio was calculated representing the percentage of owners who had done some type of cutting during the past five years. Using this calculation, the percentage of forest owners who did not file a cutting report was $53.1 \%$ of Group A and $60.0 \%$ of Group B. It is surprising that over half the forest owners, including forest advisors, did not file any cutting reports during the past five years. The percentage of forest owners who filed all cutting reports was only $12.2 \%$ in Group A and $5.0 \%$ in Group B. Why is it that such a small number of forest

Table 2 Awareness of the cutting reporting system

\begin{tabular}{|c|c|c|c|c|}
\hline \multirow[t]{2}{*}{ Answer $^{1)}$} & \multicolumn{2}{|c|}{ Group A } & \multicolumn{2}{|c|}{ Group B } \\
\hline & Number & Ratio & Number & Ratio \\
\hline I know of the system. & 327 & 49.1 & 22 & 66.7 \\
\hline I have heard of the system. & 159 & 23.9 & 4 & 12.1 \\
\hline I do not know of the system. & 168 & 25.2 & 7 & 21.2 \\
\hline No answer & 12 & 1.8 & 0 & 0.0 \\
\hline Total & 666 & 100.0 & 33 & 100.0 \\
\hline
\end{tabular}

Table 3 Filing cutting report

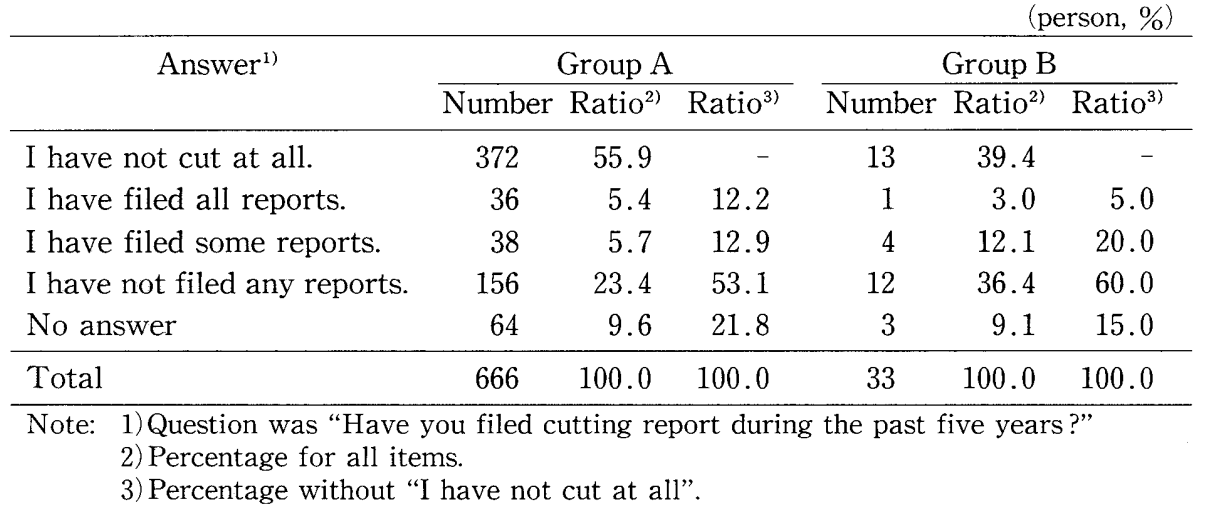


owners filed the report?

Table 4 shows the relationship between awareness of the cutting reporting system (Table 2) and the filing of cutting reports (Table 3 ). Considering of those forest owners who indicated an awareness of the cutting reporting system, 30 forest owners filed reports for all cutting activities, 26 forest owners filed reports for some cutting activities and 52 forest owners did not file at all. Thus, almost half of the forest owners who were aware of the cutting reporting system did not report their cutting activities during the past five years. Of course, almost all of the forest owners who were not aware of the system did not file reports or did not answer this question. The responses of forest owners who had only heard of the system and did not know its contents were similar to those forest owners who were not aware of the system. To increase the number of cutting reports filed, it is necessary not only to promote understanding of the system, but also to teach forest owners how to file the report with the local forestry office.

Reasons why forest owners do not report their cutting activities

As shown in Table 4, almost half of forest owners who were aware of the cutting reporting system did not report their cutting activities at all. Why did they ignore the law? Table 5 indicates some reasons. This question applied only to forest owners who did not file at all (156 persons in Group A, 12 persons in Group B) or who filed some but not all reports (38 persons in Group A, 4 persons in Group B) during the past five years (see Table 3). The number of answers for this question was 184 from Group A, a response rate of $94.8 \%$. Similarly, $81.3 \%$ of Group B responded. The percentage of answers to this question was high and indicated that the forest owners do not consider it illegal to cut their own trees without filing a report. However, it is against the Forest Law to cut trees without filing a report before the cutting activities begin. Most forest owners say they are decidedly against the rule.

Many owners (42.4\%, Table 4) also indicated that they believed that the cutting area was so small that the cutting report was not required. Generally in Japan, the management area of privately owned forest is very small and the size of forest practice is small. However, there are no regulations on cutting report relating to the size of the cutting area. A cutting report is required for all cutting activities regardless of size.

Another problem is related to the system itself. Among those responding, $32.1 \%$ indicated that they did not know of the existence of the system and $19.6 \%$ indicated

Table 4 Relationship between awareness and filing

\begin{tabular}{lrrrrrr} 
& \multicolumn{5}{c}{ Filing cutting report ${ }^{1)}$} \\
\hline \multirow{2}{*}{$\begin{array}{l}\text { Awareness of } \\
\text { the cutting reporting system }\end{array}$} & No cut & All & Part & Not filed No answer & Total \\
\cline { 2 - 7 } & 190 & 30 & 26 & 52 & 29 & 327 \\
\hline I know of the system. & 96 & 5 & 9 & 34 & 15 & 159 \\
I have heard of the system. & 78 & 1 & 2 & 70 & 17 & 168 \\
I do not know of the system. & 8 & 0 & 1 & 0 & 3 & 12 \\
No answer & 372 & 36 & 38 & 156 & 64 & 666 \\
\hline Total & &
\end{tabular}

Note: 1) Items are shown in Table 3.

Table 5 Reasons why forest owners did not file cutting report

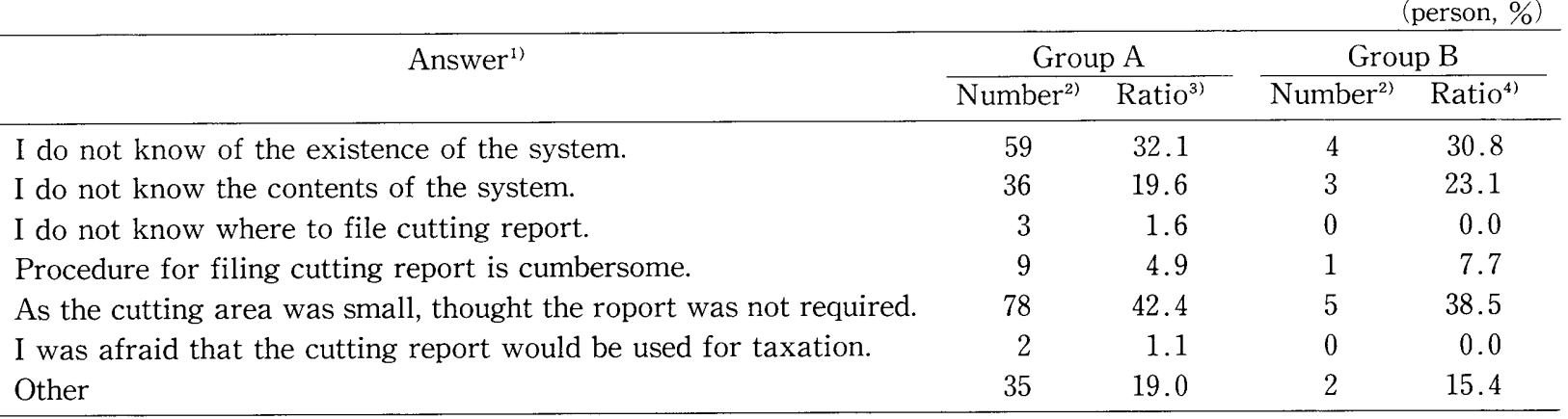

Note: 1) Question was "Why did you not file a cutting report for all of your cutting activities ?".

2) Plural answers.

3) Percentage of persons who answered this question (184 persons).

4) Percentage of persons who answered this question (13 persons). 
they did not know the contents of the system. It is a problem that such an important system is not widely and correctly understood by forest owners. In addition, it is also problem that forest owners who do not know the contents of the system tend to ignore the law. They ought to obtain advice on what to do from a forest advisor. However, as shown in Table 2, Table 3 and Table 5 , the situation is almost the same among advisors (Group B). If owners wish to obtain more information on the system, they have to go to the forestry extension agent for advice.

The percentage of answers relating to filing procedures for the cutting report was not as high. The filing procedure was considered cumbersome by $4.9 \%$ in Group $\mathrm{A}$ and $7.7 \%$ in Group B. The percentage of forest owners who answered that they were afraid to use the cutting report because of taxation was only $1.1 \%$ in Group A and 0 in Group B. This finding was limited by the questionnaire for forest owner.

It is worth considering whether small cutting activities should be reported. As already indicated, currently it is illegal not to report because of the small size of the cutting area. Article 10 of the Forest Law includes several exceptions for reporting. One exception is cutting for domestic consumption, and $37.1 \%$ of forest owners who had thinned forests less than 35-years-old during the past five years used at least some of the thinning domestically. Although cutting for domestic use is excepted under Article 10 of the Forest Law, a different form must be filed specifying that the cutting is for domestic consumption. Furthermore, cutting for domestic consumption is limited by regulations relating the Forest Law to 2ha in Hokkaido, and 1 ha outside Hokkaido. I cannot say for certain how many forest owners are aware of this rule, but probably there is lower awareness of this rule than of the cutting reporting system. Another exception under Article 10 is clearingcutting. It is possible that forest owners think of various forest practices, including cleaning-cutting, thinning, and final cutting, as "cutting". Accordingly, it is almost certain that there are some cases that do not require reporting of the cutting activities.

\section{DISCUSSION}

Importance of the cutting reporting system

In this section, the current significance of the cutting reporting system is discussed. To begin, a few remarks should be made concerning the role of the cutting reporting system after the second World War. In 1951, the Forest Law was enacted, and the permission and reporting system on cutting was created. In the 1951 law, permission was required if the forest was protected or the age of the forest was less than the specified rotation age and reports were required for other reasons. As the supply of domestic forest resources was poor because of destructive cutting during and just after the war, strict forest resource control was necessary to maintain forest resources and increase the future supply of forest products without importing. In the 1957 amendment to the Forest Law, the cutting limitation for broad-leaved trees outside protected forests was abolished, and changes were made to the reporting system. In the 1962 amendment to the law, cutting limitations for needle-leaved trees were also abolished. In the 1974 amendment, prefectural governors were given the authority to order forest owners to change their cutting plans, and a new permission system for conversion of forest land was created.

The cutting reporting system was gradually introduced, replacing the permission system for cutting activities. The main reason why the permission system was changed to the reporting system was the reduced cutting pressure on domestic forests, especially in private forests. Recently in Japan, the self-sufficiency rate of log supply has decreased, reaching $22.4 \%$ in 1994 . By comparison, the rate was over $90 \%$ in the $1950 \mathrm{~s}$. The percentage of logs imported from foreign countries has steadily increased in this time, and the productive capacity of private forests has decreased relative to that of foreign countries due to the small labor force and the delay of mechanization. The total growing stock of domestic forest resource was approximately 3,483 million $\mathrm{m}^{3}$ at the end of fiscal 1994 (FORESTRY AGENCY 1996), and the total cutting volume was 32,638 thousand $\mathrm{m}^{3}$ in fiscal 1994 (FORESTRY AGENCY 1995), so the ratio of cutting volume to growing stock is currently only $0.9 \%$. We have 158 regional forest planning areas in all of Japan, and there are no planning areas with a cutting volume exceeding the sustained yield. Under these conditions, the importance of the permission system declined.

It is possible that recently the cutting reporting system has not been enforced by prefectural governments, at least from the perspective of maintaining local forest resources. The current percentage of total growing stock that is cut $(0.9 \%)$ is not likely to increase, because the growing stock is expected to continue increasing for a while. Thus, the role of the cutting reporting system in sustaining or improving forest resources is not as important as the past role of the permission system. The cutting reporting system, however, has four other important roles.

The first role is that the cutting reporting system will contribute to building accurate databases on forests in Japan. The basic database related to forest resources, called Shinrinbo, is managed by the prefectural governments. This database includes data about forest owners and forest land. In the first category, the name of the forest owner, their occupation, whether the forest owner lives in the area, existence of an approved forest operation plan and so on are included. In the second category, compart- 
ment number, sub-compartment number, species, age, volume, volume at the cutting period, locality class, and various legal regulations are included. This is a unique database covering all private forests. However, this database has several weak points. The most serious one is the lack of an effective updating system. Basically, this database is updated by the cutting reporting form, although data from some permission forms for the conversion of forest land and several forestry programs is also used for updating. However, the most important source of updated information on forest resources is the cutting reporting form, and the percentage of reporting to actual activities is low. As a result, for example, the database may indicate an old-age forest which has actually been cut and newly replanted. Such discrepancies have been increasing, and one reason is the inadequacy of the cutting reporting system. The database requires an effective updating procedure, and the cutting reporting system can fulfill this role.

The cutting reporting system also contributes to the regional forestry economic information system. In the Japanese forestry sector, especially in the administrative sector, the utilization of computers has not progressed quickly. However, several information systems, including a Geographical Information System, have recently been considered, and various kinds of regional forestry information centers have also been suggested to assist the development of the forest economy. In Japan, the holding size of forests in the private sector is very small, and the distribution system from log production to mill is inefficient. The introduction of an information system has been widely discussed to improve domestic log supply. Information on cutting activities and an accurate forest resource database would be useful for the development of such a local forestry information system.

The third important role of the cutting reporting system relates to the requirement that forms be filed 30 days to 90 days before cutting. Most information on forest resources and forestry is ex post facto data. The cutting reporting system is reports in advance, and although currently the utilization of this cutting reporting form is almost always limited to updating the database, it could be used for forecasting regional cutting activities. In regional forest planning, forecasting the cutting volume over a planning period is important. Currently, this forecasting is a long-run estimation based on the supply side model, using Gentan Probability theory, an application of the Markov chain model. However, accurate data from the cutting reporting system could be effectively utilized. The cutting reporting form reports the area to be cut, and the cutting volume has to be calculated using other data, for example, species, age and site index. If all forest owners in a forest planning area filed their cutting schedules correctly in advance, the local forestry office or forestry information center could make short-term log supply forecasts. This would also allow optimal labor force distribution.

The fourth role of the cutting reporting system is its contribution to the understanding of the overall structure of forestry and wood related industries. The person obligated to file a cutting reporting form is, strictly speaking, the person who is planning to cut. In most case, this is forest owner himself, but sometimes, it is the buyer of standing trees. Currently, precise data on log distribution is not clear in most areas, especially concerning the buyer of standing trees. If the cutting reporting system is properly carried out, we could obtain many important economic facts for the local secondary forestry industries which would be useful for the development of local forestry policy. Recently in Japan, stumpage price and log production has decreased. As a result, the economic importance of forestry is decreasing. Establishing economic development policies in rural areas is an important issue and understanding the economic structure is the first step in developing effective local policies.

Possibility of promoting the cutting reporting system

This study found that the percentage of people filing cutting report forms is low, despite the penal provisions for cutting without reporting of Article 207 of the current Forest Law. To improve this situation, strengthening the application of the law may be an available and effective method. However, this is not in accordance with the basic philosophy of post-war forest extension policy.

First, what do forest owners think about promotion of the cutting reporting system? Table 6 shows the opinions of the advisory forest owners (Group B) on the necessity of promoting the cutting reporting system. Approximately half of the forest advisors are aware of the necessity. The problem is the other half, especially, the $27.3 \%$ of forest advisors who responded that it would be difficult to promote the cutting reporting system, although they recognize the necessity of such a program. The reasoning behind this opinion was not investigated in this questionnaire, but there may be some good reasons why forest owners do not wish to cooperate with the basic forest policy. Recently, most

Table 6 Necessity of filing promotion of cutting report

\begin{tabular}{lcc} 
& & (person) \\
\hline \multicolumn{1}{c}{ Answer ${ }^{1)}$} & Number & Ratio \\
\hline Necessary to promote local forestry & 15 & 45.5 \\
Difficult to promote & 9 & 27.3 \\
Do not understand & 1 & 3.0 \\
Other & 3 & 9.1 \\
No answer & 5 & 15.2 \\
\hline Total & 33 & 100.0 \\
\hline
\end{tabular}

Note: 1)Question was "What do you think about the promotion of filing cutting report?" 
forestry practices such as planting, thinning, and forest road construction, are performed under Government subsidy. Government subsidies also support local forest owners associations, and contribute to the construction of most forest roads. Final cutting is not subsidized, although many government subsidies may have been invested in growing the trees to final cutting age. The reporting of cutting of subsidized trees seems to be an obligation in these circumstances. Nevertheless, it is a serious situation that many forest owners even in advisory positions have given up on promoting the cutting reporting system.

Finally, I would like to conclude this analysis by making policy recommendations for promotion of the cutting reporting system. The following six points are strongly recommended.

(1) Since recognition of the system is low, activities related to disseminating information about the cutting reporting system must be initiated. There are many opportunities for publicity campaigns, for example, the annual meetings of forest owners associations, regular meetings in the community, discussion meetings between town or village offices and inhabitants, and training courses on forestry techniques.

(2) Promotion and teaching about the system is also necessary. Owners need to be taught when reporting is required, how to file the form, where to file the form, and the definition of exceptional cases. Of forest owners who indicated awareness of the cutting reporting system in Table 2 , approximately half of the forest owners did not understand the system in detail. Materials are also needed for forest advisors to promote the system.

(3) It is also important that forest owners also understand the roles of the cutting reporting system in the development of forestry planning policy. Although the size of cutting areas is generally small in Japan, gathering data of small cutting areas can help identify patterns in cutting activities. As further changes are made in forest management, the role of the cutting reporting system will increase.

(4) Improvements in the cutting reporting system must be simultaneous with improvements in the utilization system. One reason for the inadequacy of the current system is the poor use of the information. The system includes useful information for local forestry management, and can be used to update resource databases, in return providing better information for planning and management.

(5) The current system has several weak points in practice. For example, some of the exceptions enacted in Article 10 of the Forest Law are complicated and more simple rules would be easier to understand. For example, "all cutting activities except cleaning-cutting must file a report" would be more understandable for forest owners. Modifications are also needed to cope with the various cutting methods that have been introduced into private forest management recently. In the current cutting report- ing system, the clear-cutting system is assumed to be the standard.

(6) The cutting reporting system is important for managing forest resources at the local level. An extension program, including the advisory system, facilitates communication between the administrative office and the numerous forest owners. However, responses to this questionnaire suggested that forest advisors and extension staff have not played an adequate role, at least in this survey area. A program to improve the extension sector is also needed.

\section{CONCLUSION}

In this paper, the current status of the cutting reporting system in Japan has been clarified using a questionnaire in Hokusatsu Forest Planning Area in Kagoshima Prefecture. The cutting reporting system replaced the cutting permission system initiated after the Second World War. Since then, great changes have occurred in economic development, social conditions in mountainous regions and forestry conditions, but the system has remained unchanged. As a result, many forest owners do not even know of the existence of the cutting reporting system, and the forest resource database contains many errors resulting from cutting reports not being filed. In the information age, the cutting reporting system assumes new roles in addition to its traditional roles. Strengthening the publicity given to the cutting reporting system as well as restructuring the system itself would be highly advantageous to local forestry development.

\section{ACKNOWLEDGEMENT}

I would like to thank Kagoshima Prefecture Forest Owners Association who conducted the questionnaire and the forest owner who responded. The questionnaire was carried out as part of the labor conditions survey project in fiscal 1995. This research was funded by the Grant-in-Aid for Scientific Research of the Ministry of Education, Science and Culture of the Government of Japan (fiscal year 1996, Research number 08209112, Subject: An analysis on the effective utilization of micro-data on private forest).

\section{LITERATURE CITED}

Forestry AGEnCy, (1992): Statute book on forestry (1992 ed.) *. Rinnya Kousaikai, Tokyo, 31, 47, 66 (in Japanese)

Forestry Agency, (1995): Statistical handbook of forestry (1995 ed.)* Rinnya Kousaikai, Tokyo, 34 (in Japanese)

Forestry AgEncy, (1996): White paper on forestry (fiscal 1995 ed.)*. Nihon Ringyou Kyoukai, Tokyo, 137 (in Japanese) 
Iwata, H. and Fujiwara, M., (1994): Factors causing cutting-activities. Res. Bull. Fac. Agr. Gifu Univ. 59: 63-71 (in Japanese with English summary)

Kagoshima Prefectural Government, (1995): Local forest planning*. Hokusatsu Forest Planning Area (planning period is from 1 April 1995 to 31 March 2005), 1-4, 128 (in Japanese)

MAtsushitA, K., (1996): Reports on forestry workers conditions in Kagoshima prefecture. Hokusatsu Forest Planning Area, 64-69 (in Japanese)

Matsushita, K., Fujiwara, M. and Iwata, H., (1994): A statistical analysis on cutting-activity - Recent trends of cutting-age in Gifu prefecture. Bull. Kagoshima Univ. Forest 22: 51-67 (in Japanese with English summary)

Matsushita, K., Hirata, K., FujiKake, I. and Ono, S., (1992): Study on the cutting-pattern and the forecasting-method applicable to timber -supply. Bull. Fac. Agr. Kagoshima Univ. 42: 149-163 (in Japanese with English summary)

Shinkin Keikaku Seido Kenkyukai, (1992): Administrative work on forest planning (new ed.)*. Chikyu-sha, Tokyo, 256-282 (in Japanese)

SHIRAISHI, N., (1994): An analysis of forestry operation's intensity from the view point of accessibility. J. Jpn. For. Soc. 76: 218-223 (in Japanese with English summary)

Yamamoto, Y. and Kageyama, N., (1994): Current situation on nonclear cutting practices in Ibigawa Area*. Kaihou (Shinrin keikaku Kenkyukai) 363: 38-47 (in Japanese)

* The titles are tentative translations from original Japanese titles by the author of this paper.

(Received 26 June 1996)

(Accepted 15 July 1996) 